\title{
PENGARUH TAMPILAN DAN KONTEN TERHADAP EFEKTIVITAS PROMOSI MELALUI WEBSITE PADA PT.ELEGANT TOUR AND TRAVEL MEDAN
}

\author{
Angela Ariani \\ NIDN 0530106001 \\ Email: angelabam60@gmail.com \\ Sekolah Tinggi Pariwisata AMPTA Yogyakarta \\ Destri Natali Banjarnahor \\ Sekolah Tinggi Pariwisata AMPTA Yogyakarta
}

\begin{abstract}
The research is a quantitative research that aims to determine the effect of the display and content on the effectiveness of promotions through the website on PT. Elegant Tour and Travel Medan.This research is conducted by observing PT. Elegant Tour and Travel Medan's website directly. Data collection methods are conducted by spreading online questioners to 96 respondents. The sample selection technique using random sampling. Data from 96 respondents were then analyzed through multiple linear regression analysis with the help of SPSS 20.The result showed adjusted $r$ square value of 0,440 means that $44 \%$ of the effectiveness of promotion through the website is influenced by display and content while about 56\% is influenced by another factors out of research. The result of testing regression coefficient simultaneously obtained $f$ count of 38,324 > $f$ table which is 3,09 with significance value 0,000 <0,05. Partial result of hypothesis testing obtained $t$ count of display $>t$ table content $(2,275>1,98552)$ and $t$ count content $>t$ table (8,077>1,98552). From this test it can be conclude that display and content have a positive and significant effect on the effectiveness of promotion through the website on PT. Elegant Tour and Travel Medan.
\end{abstract}

Keyword : Display, Content, The Effectiveness Of Promotion Through The Websit 


\section{PENDAHULUAN}

Pariwisata merupakan salah satu industri terbesar didunia dan merupakan aset yang dapat meningkatkan pendapatan nasional, pendapatan daerah serta mempengaruhi dan meningkatkan devisa negara. Pada saat ini pemerintah Indonesia menempatkan pariwisata Indonesia sebagai sektor perioritas utama, leading sector, dan sekaligus menjadikan core economy bangsa Indonesia.

Kementerian Pariwisata (KEMENPAR) guna menggeliatkan sektor pariwisata Indonesia. Go Digital memang menjadi salah satu program Kemenpar yang tengah dijalankan untuk kemajuan pariwisata Indonesia. Tiga program utama Kementerian Pariwisata untuk mengembangkan pariwisata Indonesia yaitu Go Digital, Homestay Desa Wisata, dan Aksesbilitas Udara atau Konektivitas. Kini format urusan pariwisata makin gampang dengan digitaliasi, salah satu contohnya transaksi pemesan tiket paket wisata secara online. Sumber daya manusia di sektor pariwisata mesti akrab dalam persoalan digitalisasi, alasannya yaitu karena para wisatawan saat ini melek teknologi. 70 persenwisatawan sudah share and search menggunakan digital.

Menurut http://www.kemepar.go.id, yang diakses pada tanggal 11 Mei 2018, KEMENPAR Bapak Arif Yahya menyatakan bahwa konsumen sudah berbeda jauh perilakunya menjadi semakin digital atau yang dikenal dengan istilah "Always Connected Travellers", dimanapun dan kapanpun wisatawan akan saling terkoneksi dengan adanya mobile apps atau devices. Jika sektor pariwisata tidak mengikuti perubahan konsumen dengan menggunakan media digital dan mengikuti perkembangan teknologi atau $G o$ digital ,pasti akan mati. Gaya hidup wisatawan dalam mencari informasi destinasi, memperbandingkan antar produk, memesan paket wisata dan berbagi informasi kini telah mereka lakukan dengan menggunakan media digital. Semakin digital cara sektor pariwisata menarik wisatawan maka akan bisa menjangkau konsumen global dari manapun di seluruh dunia. Pemanfaatan Go digital ini dengan memasuki digital marketing.

Advertising atau periklanan merupakan salah satu bentuk bauran promosi non personal dengan mengunakan media yang ditunjukan untuk menarik minat pembeli. Iklan yang efektif akan memberi banyak manfaat bagi perusahaan, diantaranya yaitu sebagai sumber informasi, mempengaruhi dan membujuk konsumen, menciptakan image yang baik, serta sebagai alat komunikasi antara penjual dan pembeli. Internet dan online disebut sebagai lalu lintas informasi yang sangat cepat, menghubungkan komputer-komputer di seluruh dunia dalam satu jaringan atau sistem yang lebih besar untuk dapat bertukar informasi baik text, gambar, audio, video dan lainnya. Salah satu media promosi melalui internet dan online adalah Website.

Promosi melalui Website memiliki keunggulan tersendiri, antara lain; iklan yang dipromosikan menyebar ke seluruh pelosok negeri bahkan ke seluruh dunia sehingga iklan tersebut dibaca oleh banyak orang, pemasangan iklan yang relatif mudah dan isi iklan dapat diubah setiap hari. Kegiatan promosi melalui website dapat dikatakan efektif jika tampilan beserta isi yang terdapat dalam website tersebut dapat mempengaruhi keputusan pengunjung website untuk membeli produk atau jasa yang ditawarkan di dalam website.

PT. Elegant Tour and Travel Medan merupakan salah satu travel agent yang berada di kota Medan. Perusahaan ini menggunakan Website sebagai media promosinya. PT. Elegant Tour and Travel Medan belum optimal dalam memanfaatkan Go Digital, salah satunya dalam memanfaatkan media Website.

Pada saat ini banyak perusahaan yang sudah mengikuti program Go Digital, persainganpun juga semakin ketat apabila perusahaan tidak maksimal dalam memanfaatkan Go Digital khususnya Website, maka perusahaan akan gagal dalam persaingan pasar. 
Penelitian ini difokuskan pada pengaruh tampilan dan konten terhadap efektivitas promosi melalui website pada PT. Elegant Tour and Travel medan dengan tujuan utama untuk meningkatkan kegiatan promosi melalui website.

\section{LITERATUR RIVIEW}

\section{Promosi}

Menurut Ali Hasan (2009:367) menyatakan bahwa promosi adalah suatu bentuk

kegiatan komunikasi pemasaran yang berusaha untuk menyebarkan informasi, mempengaruhi, mengingatkan pasar sasaran agar bersedia menerima, membeli dan loyal pada produk yang ditawarkan oleh perusahaan yang bersangkutan. Promosi terkait dengan bauran promosi. Adapun bauran promosi menurut Ali

Hasan (2013:603) adalah periklanan (advertising),penjualan personal (personal selling), promosi penjualan (sales promotion), hubungan masyarakat (public relation), pemasaran langsung (direct marketing), dan online marketing.

Periklanan (advertising) disebut sebagai penjualan non-personal untuk

menginformasikan, membujuk dan mengingatkan pelanggan mengenai produk, jasa dan pelayanannya. Periklanan ini dapat dilakukan oleh perusahaan atau pengusaha melalui surat kabar, radio, majalah, bioskop, televisi, internet ataupun dalam bentuk poster- poster yang dipasang di pinggir jalan atau tempat-tempat yang strategis.

\section{Internet}

Menurut Alexander F.K Sibero (2011:10), internet (Interconneted Network) adalah jaringan komputer yang menghubungkan antar jaringan secara global, Internet dapat juga disebut jaringan alam suatu jaringan yang luas.

Sedangkan menurut Yoka Ifana Putra (2015:13), internet dapat diartikan sebagai jaringan komputer luas dan besar yang mendunia, yaitu menghubungakan pemakai komputer daru suatu negara ke negara lain di seluruh dunia, dimana di dalamnya terdapat berbagai sumber daya informasi dari mulai yang statis hingga dinamis dan interaktif.

Selain itu Internet dapat disebut sebagai sumber daya informasi yang dapat digunakan oleh seluruh dunia dalam mencari informasi. Istilah yang sering ditemukan dalam aplikasi marketing lewat internet, seperti internet marketing, digital marketing, online marketing, virtual marketing, cyber

\section{Pengertian $\boldsymbol{E}$-Marketing}

E-marketing dimaknai sebagai penggunaan teknologi digital atau internet untuk mencapai tujuan pemasaran,termasuk upaya-upaya pengembangan atau penyesuaian konsep pemasaran itu sendiri, berkomunikasi dalam jaringan global, mengubah cara perusahaan melakukan bisnis dengan pelanggan dan mempromosikan sebuah web bisnis untuk tujuan komrsial.

Menurut Ali Hasan keunggulan E-marketing yaitu :

$(2013: 761)$

1. Meningkatkan profil organisasi yang memungkinkan perusahaan untuk meraih penggan yang sebelumnya di luar jangkauan perusahaan

2. Meningkatkan penjualan, market share, profitabilitas dan return on investment

perusahaan

3. Mengurangi biaya ( lebih efisien) dan dapat melakukan berbagai kegiatan pemasaran dalam waktu singkat (lebih efektif)

4. Menciptakan nilai tamabah bagi konsumen dan kepuasan konsumen

5. Mengembangkan berbagai interaksi dengan konsumen

6. Memungkinkan memperoleh umpan balik (feedback) dari pelanggan secara langsung

7. Meningkatkan kemampuan untuk menyajikan dan mengupdate informasi secara interaktif

Menurut Ali Hasan (2013:767) jenis-jenis pilihan yang termasuk dalam ranah $E$ marketing untuk mendukung kegiatan pemasaran sebagai berikut :

1. E-Commerce 
Model bisnis dalam menjual produk dengan tiga kemungkinan produk dijual langsung ke konsumen, perusahaan menjual produk ke perusahaan lain, konsumen menjual produk ke konsumen lain

2. Lead based website

Strategi dimana perusahaan menghasilkan nilai dari penjualan melalui website

3. Affilate marketing

Sebuah proses dimana produk yang dikembangkan oleh satu entitas untuk dijual oleh penjual lain dengan berbagi keuntungan

\section{Display advertising}

Tampilan iklan melibatkan penggunaan iklan banner yang ditempatkan di website pihak ketiga untuk mengarahkan lalu lintas ke website perusahaan itu

\section{E-mail marketing}

Perusahaan yang menggunakan email mengirim promosi secara langsung kepada pelanggan

6. Interactive advertising

Ilkan interaktif melibatkan penggunaan animasi dan teknik grafis lainnya untuk membat iklan yang melibatkan ausiens

7. Search engine marketing

Serangkaian taktik online melalui mesin pencari untuk meningkatkan eksposure dan lalu lintas website perusahaan

8. Viral marketing

Penyampaiian informasi interaktif secara berantai misalnya melalui email interaktif atau video

9. Local interne marketing

Strategi dimana perusahaan kecil menggunakan media sosial untuk promosi penjualan online

\section{Pengertian Website}

Menurut Yoka Ifana Putra (2015:17) website adalah kumpulan halaman-halaman yang digunakan untuk menampilkan suatu informasi, gambar gerak, suara, atau gabungan dari semuanya baik berupa statis maupun dinamis yang membentuk satu rangkaian pada bagunan yang saling terkait dimana setiap masing-masing dihubungkan dengan link-link.

Menurut Asep Herman Suyanto (2009:3) , desain web adalah seni dan proses dalam menciptakan halaman web tunggal atau keseluruhan dan bisa melibatkan estetika seluk

- beluk mekanis dari suatu operasi situs web yang utama memusatkan pada look and feel dari situs web tersebut.

Sedangkan menurut Yoka Ifana Putra (2015:20) menyatakan bahwa desain web sangat menentukan kualitas dan keindahan dari suatu website.

Menurut Asep Herman Suyanto (2009:19) ada beberapa hal yang harus diperhatikan untuk membuat Website yang menarik bagi para pengguna Internet, yaitu sebagai berikut :

1. Background Website yang menarik

Warna latar dari sebuah homepage sangat berperan dalam memberi kesan pertama pada pengunjung homepage. Bila warna latar terlalu dominan hingga membuat text tidak dapat dibaca sama sekali, tentu saja akan memberi kesan buruk bagi pengunjung homepage. Hal ini sangat disayangkan bila ternyata isi homepage sangat bagus atau menarik dan menjadi mubazir hanya karena faktor warna latar. Untuk membuat halaman web lebih atraktif dan menarik, dapat mengganti warna latar belakang dengan gambar background. Maksud gambar background di sini adalah menggunakan gambar sebagai pengganti warna latar. File yang umum digunakan adalah file yang memiliki format GIF (Grafic Interchange Format) dan JPEG (Joint Photographic Engineering Group). Internet Explorer sendiri mensupport PNG (Portable Network Graphic) dan BMP.

Jangan menggunakan gambar berukuran satu layar penuh sebagai latar belakang,

hal ini akan membuat pengunjung stress akibat proses downloadingnya lama. Akan lebih baik bila menggunakan background yang berukuran kecil, sehingga proses download tidak memakan waktu yang lama.

\section{Tipografi}

Tipografi adalah seni huruf meliputi pemilihan huruf, penentuan ukuran yang tepat, dimana teks dapat diputus, spasi jarak, dan bagaimana teks dengan mudah dibaca. 
Ada beberapa hal yang harus diperhatikan dalam menata huruf pada halaman web antara lain :

1) Jangan menggunakan jenis huruf lebih dari 2 tipe untuk teks

2) Jangan gunakan justify, rata kanan, dan tengah

Penggunaan rata kanan pada teks akan membuat teks sulit dibaca, karena huruf latin dibaca dari kiri kekanan. Teks pada posisi tengan pun demikian.

3. Membangun navigasi situs yang baik

Navigasi pada sebuah situs adalah merupakan sebuah petunjuk jalan atau peta,

memberikan pilihan kepada pengunjung bagaian mana yang akan dikunjungi.

4. Menambahkan background suara

Menamahkan backgound suara atau lagu di dalam homepage adalah perlu untuk membuat semarak homepage.

5. Proses loading situs web harus cepat

Terkadang suatu situs web memiliki content yang menarik ataupun memiliki desain

yang indah kurang mendapat perhatian dari penjelajah internet. Itu bisa terjadi bila situs tersebut membutuhkan waktu yang sangat lama untuk loadingnya (terutama loading image) dan hal ini akan membuat pengunjung situs menjadi bosan.

Para pengguna internet menginginkan informasi yang tersaji dengan cepat. Dalam

membuat situs perlu diperhatikan pembuatan desain web maupun grafis yang indah tapi dari segi ukuran file- filenya cukup kecil.Hal tersebut perlu dipikirkan untuk mengantisipasi para pengunjung situs yang koneksi Internetnya tidak terlalu cepat.

6. Resolusi monitor dan gambar

Perbedaan resolusi pada monitor menyebabkan perbedaan ukuran pada gambar yang ditampilkan. Resolusi yang lebih kecil menyebabkan monitor menampilkan objek lebih besar. Untuk gambar-gambar yang digunakan pada halaman web, sebaiknya menggunakan resolusi 72 pixel per inch untuk mempertahankan gambar agar tetap kecil dan tampilan gambar akan sebanding dengan resolusi yang dapat dibaca oleh komputer.

7. Menentukan warna

Hal utama yang harus dilakukan adalah menenukan warna pokok, yaitu warna mayoritas yang digunakan didalam situs. Warna ini akan digunakan sebagai background, header, atau bagian lain yang memiliki porsi terbesar. Bisa mengunakan warna yang terdapat didalam logo sebagai warna-warna penyusun situs web yang akan dibuat dan bisa juga diambil dari padanan warna yang ada pada logo.

8. Buat isi homepage selalu di update

Suatu situs web yang baik akan selalu menunjukkan seringnya content diperbaharui

: ditambah, diganti, dikoreksi, dipriksa link-nya, dan lain-lain, menunjukkan bahwa situs yang dikelola adalah situs yang benarbenar terurus.

9. Membuat buku tamu

Untuk mengetahui siapa saja yang telah berkunjung ke home page yang dikelola dan bagaimana komentar atau kesankesan pengunjung mengenai homepage tersebut untuk itu dapat menggunakan GUESTBOOK.

10. Menambahkan web-counter

Untuk mengetahui jumlah pengunjung yang telah mengakses homepage gunakanlah fasilitas web-counter. Webcounter berfungsi untuk mencatat pengunjung yang pernah mengakses homepage.

\section{Pengertian Konten (Contents)}

Menurut Asep Herman Suyanto (2009:64) konten dalam website sangatlah penting, karena konten merupakan bagian dari website yang berfungsi memberikan informasi. Konten yang baik akan menarik, relevan, dan pantas untuk target audien dalam situs

web tersebut.

Menurut McLeod dalam Sutopo (2012 : 90), informasi adalah data yang berguna yang diolah sehingga dapat dijadikan dasar untuk pengambilan keputusan yang tepat. Informasi promosi terkait dengan 
pesan periiklanan yang disampaikan melalui media- media yang telah dipilih, termasuk media Website.

Menurut Hengky Alexander Mangkulo (2010 : 172), menu-menu serta informasi paling mendasar biasanya ada dalam suatu Website bisnis adalah sebagai berikut :

\section{Home}

Berisi penjelasan singkat mengenai perusahaan, produk yang ditawarkan, dan sekilas informasi lainnya.

\section{Product}

Bagian ini berisi detail dan harga produk yang ditawarkan oleh perusahaan

3. About Us

Berisi penjelasan lebih detail tentang perusahaan. Visi dan misi perusahaan bisa diletakkan dalam bagian ini, atau bisa juga dalam artikel visi dan misi terpisah.

\section{Contact Us}

Berisi informasi alamat perusahaan, nomor telepon, nomor faksimili, email dan

sebagainya, dan sebagai sarana bagi pengunjung untuk berinteraksi lebih lanjut.

5. FAQ (Frequently Asked Questions)

FAQ merupakan sebuah kenyamanan bagai para pengunjung situs

\section{Efektivitas Website sebagai Media Promosi}

Efektivitas menurut KBBI ialah suatu hal yang memiliki pengaruh, manjur, membawa hasil, dan berhasil atas suatu usaha atau tindakan. Dengan kata lain sesuatu hal dapat dikatakan berhasil dilihat dari tercapainya suatu tujuan.

Hamidi (2008) dalam Irmawati menemukakan bahwa, sebuah pesan dapat dikatakan efektif jika; pesan yang disampaikan dapat dipahami oleh komunikan, komunikan bersikap atau berperilaku seperti yang dikehendaki oleh komunikator, dan ada kesesuaian antar komponen.

Menurut Kotler dan Keller (2009:186) model AIDA (attention, interest, desire, action) merupakan model yang paling sering digunakan untuk mengetahui efektivitas promosi dari sebuah produk atau jasa. Proses AIDA berawal dari timbulnya perhatian atas barang dan jasa (Attention), memuat ketertarikan terhadap produk (Interest), memuat keinginan untuk memiliki produk ( Desire), dan mengajak pelanggan untuk melakukan tindakan dalam pembelian produk (Action). Tahapan AIDA menurut Rangkuti (2009) dalam Aufa meliputi :

1. Perhatian (Attention)

Menimbulkan perhatian pelanggan berarti pesan harus dapat menimbulkan perhatian baik dalam bentuk media yang disampaikan. Perhatian itu bertujan secara umum atau khusus kepada calon konsumen atau konsumen yang akan dijadikan target sasaran. Hal tersebut dapat dikemukakan lewat tulisan dan gambar yang menonjol dan jelas, perkataan yang menarik atau mudah dingat.

\section{Ketertarikan (Interest)}

Tertarik berarti pesan yang disampaikan menimbulkan perasaan ingin tahu, ingin

mengamati, dan ingin mendengar serta melihat lebih seksama. Hal tersebut terjadi karena adanya minat yang menarik perhatian konsumen akan pesan yang ditujukan.

\section{Keinginan ( Desire)}

Pemikiran terjadi dari adanya keinginan ini, berkaitan dengan motif dan motivasi

konsumen dalam membeli suatu produk. Motif pembelian dibedakan menjadi dua yaitu motif rasional dan emosional. Motif rasional mempertimbangkan konsumen akan keuntungan dan kerugian yang didapatkan, sedangkan motif emosional terjadi akibat emosi akan pembelian produk yang ditawarkan.

\section{Tindakan (Action)}

Tindakan terjadi dengan adanya keinginan kuat konsumen sehingga terjadi pengambilan keputusan dalam melakukan pembeli produk yang ditawarkan

\section{METODE PENELITIAN}

Penelitian ini mengambil lokasi di PT.Elegant Tour and Travel Medan, dengan mengambil jenis penelitian Kuantitatif Deskriktif. Sampel dalam penelitian ini adalah calon pembeli paket wisata pada Website PT.Elegant Tour and 
Travel Medan. Teknik pengambilan sampel dalam penelitian ini adalah random sampling. Metode pngumulan data dengan mengobservasi langsung website pada website PT.Elegant Tour and Travel Medan. Metode analsis menggunakan Regresi Linear Berganda.

\section{HASIL PENELTIAN DAN PEMBAHASAN}

1. Deskripsi PT.Elegant Tour and Travel Medan

PT. Elegant Tour and Travel Medan adalah Badan Usaha Biro Perjalanan Wisata (BPW) yang berada di kota Medan beralamat di Jl. A.H. Nasution No. 92 BB Medan. PT. Elegant Tour and Travel Medan mempunyai fokus dalam menangani paket wisata, reservasi hotel dan reservasi car rental di Sumetera. PT. Elegant Tour and Travel Medan didirikan pada tahun 2008 oleh Bapak Simon Bangun sebagai Owner perusahaan. Beliau memiliki pengalaman lebih dari 15 tahun dalam membimbing dan membawa kelompok/group dalam memimpin pasar domestik maupun luar negeri di Mutiara Holidays Medan.

Pangsa pasar dari PT. Elegant Tour and Travel Medan adalah Malaysia, Singapore, dan Indonesia sendiri. PT. Elegant Tour and Travel Medan terus maju dengan pesat sehingga mampu menjadi perusahaan yang mandiri. PT. Elegant Tour and Travel Medan sebagai salah satu Biro Perjalanan Wisata yang ada di Medan, juga menyediakan berbagai macam paket wisata seperti Amazing Tsunami Tour Aceh, Java-Bali Tours, Sumatera Overland Tours, Adventure Tours, Lake Toba Tours, dan Pilgrimage Tours. Selain paket wisata PT. Elegant Tour and Travel Medan juga memiliki jasa layanan transportasi sendiri seperti Avanza, Innova, Izusu ELF Short and Long, Mini bus dan New Jet Bus. PT. Elegant Tour and Travel Medan mempunyai motto "Commitment To Excellent", yang memiliki arti menjadikan travel ini lebih fleksibel dalam memberikan kualitas dan layanan terbaik dan menempatkan kepuasan tamu sebagai nomor satu, "Karena Senyum Pelanggan adalah Satu Juta Dollar bagi perusahaan".

PT.Elegant Tour and Travel Medan dipimpin oleh seorang Direktur.Tugas dan tanggung jawabnya adalah mejaga hubungan bisnis dengan perusahaan lain, mengurus dan mengelola kepentingan perusahaan, mengatur anggaran perusahaan, menentukan kebijaankebijakan perusahaan, dan sebagainya. Guna melaksanakan tugas dan taggung jawabnya, Direktur dibantu oleh Manager Marketing Departement, Manager Accounting, Manager Tour Departement, dan Manager Transportasi.2. Analisis Deskriptif

Karakteristik demografis responden dalam penelitian ini terdiri dari jenis kelamin,usia dan pekerjaan Ada tiga temuan riset yang terkait dengan profil segmentasi demografis responden dalam peneltian ini, yaitu sebagai berikut:

\section{a. Jenis Kelamin}

Jumlah responden yang paling tinggi adalah pelanggan yang berjenis kelamin laki-laki, yaitu sebanyak 50 orang $(52,1 \%)$ dan jumlah responden yang sedikit adalah pelanggan yang berjenis kelamin perempuan yaitu sebanyak 46 orang $(47,9 \%)$.Maka dapat disimpulkan bahwa mayoritas responden yang menjadi calon pelanggan adalah responden yang berjenis kelamin laki-laki.

b. Usia reesponden

Responden berusia 11-20 adalah sebanyak 9 orang $(9,4 \%)$, responden berusia

21-30 Tahun adalah sebnayak 57 orang $(59,4 \%)$ berusia, responden berusia

berusia 31-40 Tahun adalah sebanyak 11 orang $(11,5 \%)$, responden yang berusian 40-50 tahun adalah sebanyak 13 orang $(13,5 \%)$ dan respoden yang berusia $\geq 51$ tahunadalah sebanyak 6 orang $(6,3 \%)$. Ini berarti frekuensi usia yang leebih dominan adalah usia 21-30 (59,4\%).

\section{c. Pekerjaan Responden}

Pekerjaan 40 orang $(41,7 \%)$ dari responden adalah Pelajar/Mahasiswa, pekerjaan 
10 orang $(10,4 \%)$ dari responden adalah PNS/BUMN/ABRI, pekerjaan 32 orang $(33,3 \%)$ dari responden adalah Pegawai Swasta, pekerjaan 10 orang $(10,4 \%)$ dari responden adalah Wiraswasta, dan pekerjaan 4 orang $(4,2 \%)$ dari responden adalah Ibu Rumah Tangga.
3. Uji Kelayakan Instrumen

Uji Kelayakan Instrumen ini menyatakan uji validitas dan uji reabilitas sebagai berikut:

Tabel 2 Hasil Uji Validitas

\begin{tabular}{|l|l|l|l|}
\hline Item & Rhitung & R tabel & Keterangan \\
\hline X1.1 & 0,430 & $>0.2006$ & Valid \\
\hline X1.2 & 0,258 & $>0.2006$ & Valid \\
\hline X1.3 & 0,376 & $>0.2006$ & Valid \\
\hline X1.4 & 0,355 & $>0.2006$ & Valid \\
\hline X1.5 & 0,232 & $>0.2006$ & Valid \\
\hline X1.6 & 0,571 & $>0.2006$ & Valid \\
\hline X2.1 & 0,298 & $>0.2006$ & Valid \\
\hline X2.2 & 0,648 & $>0.2006$ & Valid \\
\hline X2.3 & 0,534 & $>0.2006$ & Valid \\
\hline X2.4 & 0,534 & $>0.2006$ & Valid \\
\hline X2.5 & 0,335 & $>0.2006$ & Valid \\
\hline X2.6 & 0,479 & $>0.2006$ & Valid \\
\hline Y.1 & 0,552 & $>0.2006$ & Valid \\
\hline Y.2 & 0,705 & $>0.2006$ & Valid \\
\hline Y.3 & 0,698 & $>0.2006$ & Valid \\
\hline Y.4 & 0,758 & $>0.2006$ & Valid \\
\hline
\end{tabular}


Hasil uji validitas berdasarkan tabel 2 menunjukkan bahwa seluruh item pertanyaan dalam kuesioner memiliki

$\mathbf{r}_{\text {hitung }}>\mathbf{r}_{\text {tabel }}$ atau lebih besar dari

0,2006, maka dapat disimpulkan bahwa semua item pertanyaan kuesioner adalah valid untuk digunakan.

b. Uji Reabilitas

Pengujian reabilitas instrumen dengan menggunakan rumus Cronbach

Alpha karena instrumen penelitian ini berbentuk angket. Hasil uji reabilitas adalah sebagai berikut:

Tabel 3 Hasil Uji Reabilitas

\begin{tabular}{|c|c|c|r|}
\hline Variabel & $\begin{array}{l}\text { Cronbach's } \\
\text { Alpha }\end{array}$ & $\begin{array}{r}\text { of } \\
\text { Items }\end{array}$ & $\begin{array}{r}\text { Kesi } \\
\text { mpulan }\end{array}$ \\
\hline Tampilan & 0,730 & 6 & Reli \\
\hline Konten (X2) & 0,744 & 6 & Reli \\
\hline $\begin{array}{c}\text { Efektivit } \\
\text { as } \\
\begin{array}{c}\text { Promosi } \\
\text { Melalui }\end{array}\end{array}$ & 0,891 & 4 & $\begin{array}{r}\text { Reli } \\
\text { abel }\end{array}$ \\
\hline
\end{tabular}

Berdasarkan tabel 3 menunjukkan hasil pengujian reliabilitas pada instrument dengan nilai Cronbach's Alpha sebesar 0,761 untuk variabel tampilan, untuk variabel konten sebesar 0,764, dan untuk variable.

efektivitas promosi melalui website sebesar 0,834. Hal ini membuktikan instrumen penelitian ini adalah reliabel karena Cronbach's Alpha untuk setiap variabel yang diteliti adalah lebih besar dari 0,70 .

4. Uji Kelayakan Variabel

Dari 96 responden (Calon pembeli paket wisata pada website PT.Elegant Tour and Travel Medan ) dilakukan uji kelayakan variabel khususnya uji normalitas variabel terikat dan uji multikolinieritas variabel bebas ditemukan didalam tabel 4 berikut ini:

Tabel 4 Hasil Uji Kelayakan Variabel

\begin{tabular}{|c|c|c|c|c|c|c|c|c|}
\hline \multirow{3}{*}{ Variabel } & \multirow{2}{*}{\multicolumn{3}{|c|}{ Normalitas }} & \multicolumn{5}{|c|}{ Uji Multikolinieritas } \\
\hline & & & & \multicolumn{2}{|c|}{ Toleransi } & \multicolumn{3}{|c|}{ VIF } \\
\hline & $\begin{array}{c}\text { Nilai } \\
\text { KS }\end{array}$ & $\geq 0,05$ & Kes & Nilai & $>0,10$ & Nilai & $<10$ & Kes \\
\hline Tampilan Website & 0,860 & 0,451 & $\mathrm{v}$ & 0,860 & $>$ & 0,982 & $<$ & $\#$ \\
\hline Konten Website & 1,285 & 0,073 & V & 1,285 & $>$ & 0,982 & $<$ & \# \\
\hline $\begin{array}{c}\text { Efektivitas } \\
\text { Promosi Melalui } \\
\text { Website Pada } \\
\text { PT.Elegant Tour and } \\
\text { Trvael Medan }\end{array}$ & 1,311 & 0,064 & $\mathrm{v}$ & 1,311 & $>$ & - & - & - \\
\hline
\end{tabular}

KS = Kolmogorov Smirnov

VIF $\quad=$ Variance Inflation Factor

Kes $\quad=$ Kesimpulan

\# $\quad=$ Tidak terjadi multikolinieritas antar variabel bebas

$\mathbf{v}=$ Semua variabel terikat mengikuti distribusi normal

Berdasarkan tabel 4 melalui pengujian Kolmogorov-Smirnov peneliti telah mengetahui bahwa data ini berdistribusi normal. Hal ini terbukti dari hasil Asymp. Sig. (2-tailed) bernilai lebih dari $0,489>0,05$. Pengujian diatas menunjukkan bahwa nilai tolerance

variabel Independen lebih besar dari 0,10 dan nilai VIF ( Variance Inflation Factor) semua variabel independen lebih kecil dari 10,00. Berdasarkan nilai diatas, disimpulkan bahwa tidak terjadi Multikolinearitas. 
5. Uji Hipotesis

a. Analisis Uji Regresi Liner Berganda

Bersarkan uji regresi linear berganda, diperoleh rumus sebagai berikut:

$\mathrm{Y}=\mathrm{a}+\mathrm{b}_{1} \mathrm{X}_{1}+\mathrm{b}_{2} \mathrm{X}_{2}$

$Y=-0,680+0,140 X_{1}+0,527 X_{2}$ 


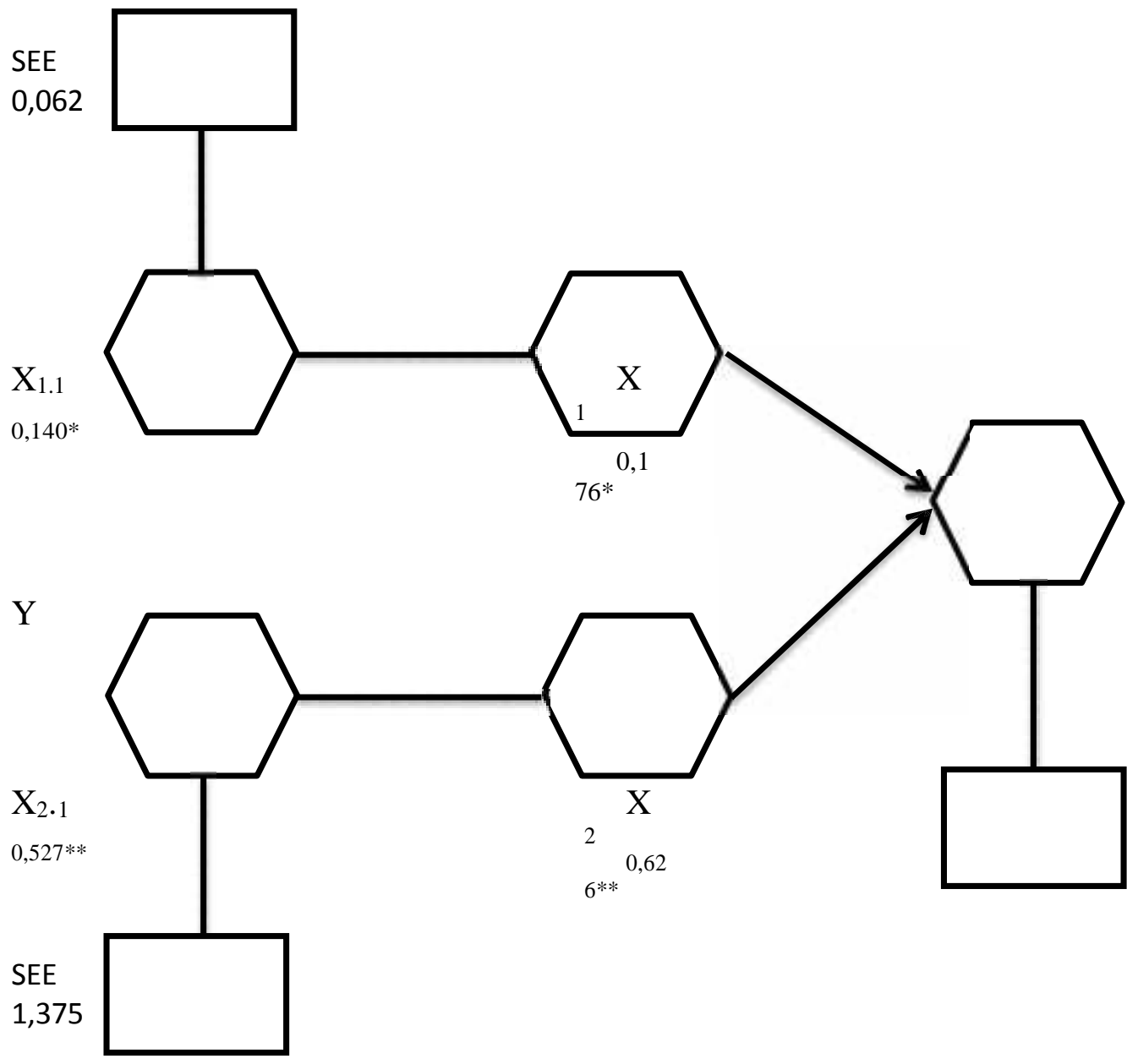

SEE

0,065

Gambar 1 Temuan Peneliian

Keterangan :

$\mathrm{X}_{1}, \mathrm{X}_{2} \quad$ : Shot Power

$\mathrm{X}_{1.1}, \mathrm{X}_{2 \cdot 1}$ : Distance Power

$\mathrm{X}_{1} \quad$ : Tampilan

$\mathrm{X}_{2} \quad$ : Konten

Y : Efektivitas Promosi Melalui Website

** : Signifikan pada 0,01. * : Signifikan pada 0,05

Interpretasi dari regresi diatas adalah sebagai berikut: 
1) Konstanta (a)

Jika semua variabel bebas (predikor) diasumsikan kosong, maka nilai variabel terikat $(\beta)$ adalah sebesar $-0,680$, berarti bahwa tanpa adanya pengaruh dari Tampilan dan Konten akan mengakibatkan berkurangnya Efektivitas promosi melalui website sebesar $-0,680$.

2) Tampilan $\left(\mathrm{X}_{1}\right)$ terhadap Efektivitas Promosi Melalui Website (Y)

Nilai kofisien regresi variabel tampilan untuk variabel $\mathrm{X}_{1}$ sebesar 0,140 atau $14 \%$. Ada tiga hal yang dapat dijelaskan dari koefisien regresi ini yaitu:

a) Bahwa Tampilan berpengaruh terhadap Efektivitas promosi melalui website.

b) Apabila variabel tampilan meningkat sebesar satu-satuan, maka akan berpengaruh meningkatkan efektivitas promosi melalui website sebesar 0,140, dan tampilan dapat meningkatkan efektivitas promosi melalui website minimal $1,34 \%$ dimasa mendatang dengan asumsi variabel lain dalam kondisi tetap (cateris paribus). Dengan adanya pengaruh yang positif ini, menunjukkan bahwa antara variabel tampilan dan efektivitas promosi melalui website mempunyai pengaruh yang searah, artinya apabila variabel tampilan meningkat maka mengakibatkan efektivitas promosi melalui website meningkat, demikian juga sebaliknya. Jika variabel tampilan menurun maka efektivitas promosi melalui website juga akan menurun.

c) Nilai standard error of the estimate (SEE) variabel tampilan dibawah 5 yaitu 0,062 , ini menunjukan bahwa tingat error model regresi dalam memprediksi nilai variabel $\mathrm{Y}$ yaitu efektivitas promosi melalui website sangat kecil, dengan demikian hubungan variabel tampilan berpengaruh signifikan terhadap efektivitas promosi melalui website pada PT. Elegant Tour and Travel Medan.

3) Konten $\left(\mathrm{X}_{2}\right)$ terhadap Efektivitas Promosi Melalui Website (Y)

Nilai kofisien regresi variabel konten untuk variabel $\mathrm{X}_{2}$ sebesar 0,527 atau $52,7 \%$ . Ada dua hal yang dapat dijelaskan dari koefisien regresi ini

yaitu:

a) Bahwa Konten berpengaruh terhadap Efektivitas promosi melalui Website

b) Apabila variabel konten meningkat sebesar satu-satuan, maka akan berpengaruh meningkatkan efektivitas promosi melalui website sebesar

0,527, dan konten dapat meningkatkan efektivitas promosi melalui website minimal $5,05 \%$ dimasa mendatang dengan asumsi variabel lain dalam kondisi tetap (cateris paribus). dengan adanya pengaruh yang positif ini, menunjukkan bahwa antara variabel konten dan efektivitas promosi melalui website mempunyai pengaruh yang searah, artinya apabila variabel konten meningkat maka mengakibatkan efektivitas promosi melalui website meningkat, demikian juga sebaliknya. Jika variabel konten menurun maka efektivitas promosi melalui website juga akan menurun.

c) Nilai standard error of the estimate (SEE) variabel konten dibawah 5

yaitu 0,065 , ini menunjukan bahwa tingat error model regresi dalam memprediksi nilai variabel Y yaitu efektivitas promosi melalui website sangat kecil, dengan demikian hubungan variabel konten berpengaruh signifikan terhadap efektivitas promosi melalui website pada PT. Elegant Tour and Travel Medan.

4) Variabel berpengaruh lebih besar atau Dominan

Konten merupakan variabel yang berpengaruh lebih besar atau dominan pada penelitian ini, karena nilai beta pada konten lebih besar dari nilai beta pada variabel tampilan yaitu $0,406>0,045$

b. Koefisien Determinasi $\left(\mathrm{R}^{2}\right)$

Tabel 5 Hasil Uji Determinasi $\left(\mathrm{R}^{2}\right)$

\begin{tabular}{|l|l|l|l}
\hline Model & $\mathrm{R}$ & R Square & Adjusted I \\
\hline 1 &, $672^{\mathrm{a}}$ &, 452 &, 440 \\
\hline
\end{tabular}


Berdasarkan tabel 5 Hasil Uji Determinasi (Uji $\mathrm{R}^{2}$ ) maka terlihat Adjusted $R$ Square sebasar 0,440. Peneliti menggunakan Adjusted $R$ Square karena lebih dari satu variabel artinya efektivitas promosi melalui website dipengaruhi oleh tampilan dan konten sebesar $44,0 \%$ sedangkan sisanya $(100 \%-44,0 \%=56,0 \%)$ dipengaruhi oleh faktor lain yang tidak diteliti dalam penelitian ini, seperti biaya promosi.

\section{PEMBAHASAN}

Penelitian ini bertujuan untuk mengetahui pengaruh tampilan $\left(\mathrm{X}_{1}\right)$ dan konten $\left(\mathrm{X}_{2}\right)$ terhadap efektivitas promosimelalui website (Y) dan untuk mengetahui variabel mana yang lebih dominan mempengaruhi efektivitas promosi melalui website pada PT. Elegant Tour and Travel Medan.

Berdasarkan hasil penelitian yang telah dilakukan, didapatkan hasil dari data responden yang telah diolah. Diperoleh karakteristik responden terbanyak berjenis kelamin laki-laki, berusia 20-30 tahun, dan pekerjaan responden pelajar/mahasiswa.

Pembahasan masing-masing variabel disajikan dalam empat bagian sebagai berikut:

Pengaruh variabel tampilan terhadap efektivitas promosi melalui website pada PT.Elegant Tour and Travel Medan Berdasarkan hasil analisis regresi berganda yang telah dilakukan dengan SPSS

20.0, maka dapat diketahui bahwa nilai variabel tampilan $\left(\mathrm{X}_{1}\right)$ koefisien regresi sebesar 0,140 atau sebesar $14 \%$. Hal ini menunjukkan bahwa pengaruh dari tampilan terhadap efktivitas promosi melalui website (Y) adalah positif.

Jika ditinjau dari uji $t$ yang telah dilakukan bahwa variabel tampilan mempunyai

$\mathrm{t}$ hitung sebesar 2,275 dan $>\mathrm{t}_{\text {tabel }}$ sebesar1.98552 dengan tingkat signifikan 0,025 . Karena $t_{\text {hitung }}>t_{\text {tabel }}$ yaitu $2,275>$ 1.98552, dengan tingkat signifikansi 0,025 $<$

0,05, hal ini berarti $\mathrm{HO}_{1}$ ditolak. Artinya tampilan merupakan variabel yang mempengaruhi efektivitas promosi melalui website pada PT.Elegant Tour and Travel Medan.

Hasil observasi menunjukkan bahwa tampilan pada website PT.Elegant Tour and Travel Medan masih kurang menarik. Dari hasil jawaban responden, indikator yang memiliki skor tertinggi pada variabel tampilan yaitu Tipografi dan proses loading website sudah cukup baik. Indikator yang memiliki skor terendah yaitu Homepage yang selalu diupdate dan background website. Website yang menarik akan selalu menunjukkan seringnya isi homepage diperbaharui baik menambah, mengganti, mengkoreksi, dan memeriksa link-link dengan isi homepage yang sering diperbaharui menunjukkan bahwa website yang dikelola adalah website yang benarbenar terurus, untuk itu sangat penting homepage website selalu diperbaharui. Background website sangat berperan penting dalam memberi kesan pertama pada pegujung ketika mengunjungi suatu website baik warna background maupun gambar yang digunakan sebagai background website.

Pengaruh variabel konten terhadap efektivitas promosi melalui website pada PT.Elegant Tour and Travel Medan

Berdasarkan hasil analisis regresi berganda yang telah dilakukan dengan SPSS 20.0, maka dapat diketahui bahwa nilai variabel konten $\left(\mathrm{X}_{2}\right)$ koefisien regresi sebesar 0,527 atau sebesar 52,7\%. Hal ini menunjukkan bahwa pengaruh dari konten terhadap efktivitas promosi melalui website (Y) adalah positif.

Jika ditinjau dari uji $t$ yang telah dilakukan bahwa variabel konten mempunyai $\mathrm{t}$ hitung sebesar 8,077 dant tabel sebesar1.98552 dengan tingkat signifikan 0,025 . Karena $t_{\text {hitung }}>t_{\text {tabel }}$ yaitu $8,077>$ 1.98552, dengan tingkat signifikansi 0,000 $<0,05$, hal ini berarti $\mathrm{HO}_{2}$ ditolak. Artinya konten merupakan variabel yang mempengaruhi efektivitas promosi melalui website pada PT.Elegant Tour and Travel Medan.

Hasil observasi menunjukkan bahwa 
konten pada website PT.Elegant Tour and Travel Medan sudah cukup menarik. Dari hasil jawaban responden, indikator yang memiliki skor tertinggi pada variabel konten yaitu Home dan Contact Us dan proses loading website sudah cukup baik. Indikator yang memiliki skor terendah yaitu Product, FAQ ( Frequently Asked Questions) dan harga. Konten adalah bagian website yang juga berperan dalam memberikan informasi kepada pengunjung website. Informasi didalam konten harus akurat, tepat waktu dan relevan. Artinya informasi yang diberikan memiliki kelengkapan yang baik, informasi yang diberikan tidak terlambat, berkualitas karena apabila informasi yang dihasilkan sebagian dan tidak bermanfaat tentunya akan mempengaruhi dalam pengambilan keputusan atau menentukan tindakan. Informasi yang lengkap mengenai product pada website perusahaan sangatlah penting, dan harus dijelaskan secara rinci sehingga pengunjung website atau calon pembeli dapat mengetahui apa saja yang akan mereka terima apabila ingin membeli produk yang ditawarkan didalam website, informasi harga juga perlu dijelaskan karena harga akan menjadi tolak ukur kualitas dari produk yang ditawarkan serta sebagai perbandingan, FAQ (Frequenly Asked Questions) didalam website juga akan membantu pengunjung website dalam memberikan informasi yang paling sering ditanyakan oleh pengunjung website, serta perlunya menambahkan live chat pada menu contact us agar calon pembeli dapat memperoleh informasi kapan saja mengenai produk yang ditawarkan didalam website.

Pengaruh variabel tampilan dan konten terhadap efektivitas promosi melalui website pada PT.Elegant Tour and Travel Medan Berdasarkan hasil analisis uji $F$ yang telah dilakukan dengan bantuan SPSS

20.0, maka dapat diketahui bahwa nilai variabel tampilan $\left(\mathrm{X}_{1}\right)$ dan konten $\left(\mathrm{X}_{2}\right)$ memiliki nilai $F_{\text {hitung }}$ sebesar 38,324 dan $F_{\text {tabel }}$ sebesar 3,09. Karena nilai $F_{\text {hitung }}$ lebih besar dari $F_{\text {tabel }}(38,324>3,09)$, dengan nilai signifikansi $0,000<0,05$, hal ini berarti bahwa HO ditolak. Dengan demikian dapat disimpulkan bahwa tampilan dan konten secara bersama-sama berpengaruh terhadap efektivitas promosi melalui website pada PT. Elegant Tour and Travel Medan.

Tampilan pada website merupakan penilain pertama sekali pengunjung

website terhadap bagus atau tidaknya suatu website sehingga memunculkan rasa ketertarikan pengunjung terhadap suatu website, konten merupakan bagian yang memberikan informasi kepada pengunjung website. Tampilan dan konten secara bersama-sama berpengaruh terhadap efektivitas promosi melalui webiste apabila tampilan di dalam website menarik tetapi isi konten didalam website tidak lengkap maka akan dapat mempengaruhi pengunjung website dalam pengambilan keputusan atau menentukan tindakan terhadap produk yang ditawarkan didalam website.

Variabel konten merupakan variabel yang berpengaruh lebih besar atau dominan terhadap efektivitas promosi melalui website pada PT. Elegant Tour and Travel Medan

Dari kedua variabel bebas yang terdiri dari tampilan dan konten, variabel konten merupakan variabel yang paling dominan dalam penelitian ini. Hasil yang didapat dalam uji regresi linier berganda, koefisien beta pada variabel konten lebih besar dari koefisien beta pada variabel tampilan $(0,406$ $>0,045)$.

Dengan demikian dapat disimpulkan bahwa variabel konten merupakan variabel yang berpengaruh lebih besar atau dominan mempengarugi efektivitas promosi melalui website pada PT. Elegant Tour and Travel Medan.

\section{KESIMPULAN}

Berdasarkan hasil penelitian, dapat disimpulkan bahwa: (1) Variabel tampilan berpengaruh positif dan signifikan terhadap efektivitas promosi melalui website. Artinya peningkatan pada setiap indikator variabel tampilan akan 
meningkatkan efektivitas promosi melalui website pada PT. Elegant Tour and Travel Medan, seperti peningkatan Background website, tipografi, pemilian warna, navigasi situs, proses loading website, dan homepage website yang selalu diperbaharui.(2) Variabel konten berpengaruh positif dan signifikan terhadap efektivitas promosi melalui website. Artinya peningkatan pada setiap indikator variabel konten akan meningkatkan efektivitas promosi melalui website pada PT. Elegant Tour and Travel Medan, seperti peningkatan pada menu home, about us, product, harga, contact us dan FAQ (Frequently Asked Questions). (3) Variabel tampilan dan konten secara serempak berpengaruh positif dan signifikan terhadap efektivitas promosi melalui website. Artinya peningkatan tampilan dan konten akan meningkatkan efektivitas promosi melalui website pada PT. Elegant Tour and Travel Medan.(4) Variabel yang lebih besar atau dominan mempengaruhi efektivitas promosi melalui website adalah konten, karena calon pelanggan lebih tertarik dan lebih memperhatikan konten website daripada tampilan website.(5) Dampak jangka panjang variabel konten jauh lebih besar dengan tingkat SE (Standard error) $<1$.

Berdasarkan hasil penelitian, Tampilan dan konten mempengaruhi efktivitas promosi melalui website. Efektivitas promosi melalui website akan meningkat jika tampilan dan konten ditingkatkan lagi, maka disarankan agar PT.Elegant Tour and Travel Medan dapat lebih optimal didalam memanfatkan website sebagai media promosi dengan meningkatkan tampilan website dan konten website. Pada tampilan website sebaiknya perusahaan lebih memperhatikan background website seperti menambahkan gambar yang merupakan ciri khas atau icon dari lokasi perusahaan atau produk yang ditawarkan, memperbaharui isi homepage. Website yang menarik akan selalu menunjukkan seringnya

\section{REFERENSI}

Agus Mulyanto. (2009). Sistem Informasi isi homepage diperbaharui baik menambah, mengganti, mengkoreksi, dan memeriksa link-link dengan isi homepage yang sering diperbaharui menunjukkan bahwa website yang dikelola adalah website yang benarbenar terurus, untuk itu sangat penting homepage website selalu diperbaharui. Konten berpengaruh lebih besar terhadap efektivitas promosi melalui website daripada tampilan. Hal ini sudah baik, tetapi untuk lebih meningkatkan efektivitas promosi melalui website maka perusahaan disarankan agar lebih meningkatkan konten website dengan memperhatikan produk, harga dan FAQ (Frequently Asked Questions). Informasi yang lengkap mengenai produk pada website perusahaan sangatlah penting, dan harus dijelaskan secara rinci sehingga pengunjung website atau calon pembeli dapat mengetahui apa saja yang akan mereka terima apabila ingin membeli produk yang ditawarkan didalam website, informasi harga juga perlu dijelaskan karena harga akan menjadi tolak ukur kualitas dari produk yang ditawarkan serta sebagai perbandingan, FAQ (Frequenly Asked Questions) didalam website juga akan membantu pengunjung website dalam memberikan informasi yang paling sering ditanyakan oleh pengunjung website, serta perlunya menambahkan live chat pada menu contact us agar calon pembeli dapat memperoleh informasi kapan saja mengenai produk yang ditawarkan didalam website.

Keterbarbatasan dalam penelitian ini hanya fokus pada variabel tampilan dan konten dan tidak melihat keterkaitannya variabel lain misalnya variabel biaya promosi dan metode pencarian yang digunakan hanya dengan penyebaran kuesioner kepada 96 responden, oleh karena itu untuk penelitian mendatang dapat menggunakan variabel biaya promosi dan metode lain dalam pencarian data seperti wawancara langsung kepada responden

Konsep dan Aplikasi. Yogyakarta: Pustaka Pelajar.

Alexander F.K Sibero. (2011). Web 
Programing. Yogyakarta : MediaKom

Ali Hasan. (2009). Marketing. Yogyakarta: Media Pressindo

Ali Hasan. (2013). Marketing dan KasusKasus Pilihan. Yogyakarta: CAPS (Center for

Academic Publishing Service)

Ariesto Hadi Sutopo. Teknologi Informasi dan Komunikasi Dalam Pedidikan.Yogyakarta: Graha Ilmu

Asep Herman Suyanto. (2009). Step by Step Web Design Theory and Practies. Yogyakarta: Penerbit Andi

Detik.com. (2017). Menpar Arief: Digitalisasi Wajib Diajarkan di Perguruan Tinggi

Pariwisata,(Online).https://travel.detik.com/t ravel-news/d3445893/menpar-ariefdigitalisasi-wajib-diajarkan-diperguruan tinggi-pariwisata, diakses pada tanggal 10 November 2017)

Didih Suryadi. (2011). Promosi Efektif Menggugah Minat \& Loyalitas Pelanggan. Yogyakarta: Orya

Elegant Tour and Travel.(www.eleganttours.com, diakses bulan November 2017, Januari, Februari 2018)

Hengky Alexander Mangkulo. (2010). Membuat Web Company Profile Dengan Joomla. Jakarta: PT. Elex Media Komputindo

Jazaul Aufa. (2014). Efektifitas Website Sebagai Media Komunikasi Pemasaran Kampoeng Wisata Bisnis Tegalwaru, Cimpea, Bogor, Jawa Barat. Bogor. Institut Pertanian Bogor

Kementrian Pariwisata Indonesia.2017. Go Digital The More Digital, The More Personal.The More Digital Digital, The More Profesional. The More Digital, The More Global. (http://www.kemepar.go.id/asp/detil.as $\mathrm{p} ? \mathrm{c}=193$ \&id $=3328$, yang diakses pada tanggal 11 Mei 2018)

Kotler \& Keller. (2009). Manajemen Pemasaran. Jakarta: Erlangga
Maryono, $\mathrm{Y} \quad \& \quad \mathrm{~B}$. Patmi Istiana. (2008). Teknologi Informasi dan Komunikasi. Bandung: Quadra

Nabila Rahma Irawati. (2016). Efektivitas Website Sebagai Media Promosi Agrowisata Gunung Mas, Bogor, Jawa Barat.Bogor.Institut Pertanian Bogor

Sugiyono. (2011). Metode Penelitian Kuantitatif Kualitatif Dan $R \& D$.Bandung. Alfabeta

Sugiyono. (2014). Statistika Untuk Peneitian. Bandung: Alfabeta

Sugiyono. (2018). Metode Penelitian Kuantitatif. Bandung: Alfabeta

Suhasimi Arikunto. (2010). Prosedur Penelitian Suatu Pendekatan Praktik. Jakarta: Rineka Cipta

Yoka Ifana Putra. (2015). Buku Pintar Membuat Website. Jakarta Selatan: Ufuk Cyber 